\title{
Spatial and temporal variation of fish assemblages in a coastal lagoon of the Biosphere Reserve La Encrucijada, Chiapas, Mexico
}

\author{
Ernesto Velázquez-Velázquez ${ }^{1,2}$, M. Eugenia Vega-Cendejas ${ }^{2}$ \& Jorge Navarro-Alberto ${ }^{3}$ \\ 1. Escuela de Biología, Universidad de Ciencias y Artes de Chiapas, Libramiento Norte Poniente s/n, Tuxtla Gutiérrez, \\ Chiapas, México; ernestov@mda.cinvestav.mx \\ 2. CINVESTAV-IPN, Unidad Mérida, Km 6 Antigua Carretera a Progreso, A.P. 73 Cordemex, CP 97310, Mérida, \\ Yucatán, México; maruvega@mda.cinvestav.mx \\ 3. Universidad Autónoma de Yucatán, FMVZ, Dpto. de Ecología, Km. 15.5 Carretera Mérida-Xmatkuil, Mérida, \\ Yucatán, México; nalberto@uady.mx
}

Received 22-V-2007. Corrected 26-XI-2007. Accepted 04-IV-2008.

\begin{abstract}
Composition and abundance of the ichthyofauna in estuarine and coastal lagoon systems of the South Pacific in Mexico have been scarcely studied. In particular, there is a lack of information on how environmental variables determine the spatio-temporal structure of fish assemblages in those habitats. In this study, fishes were sampled by drop net during twelve months (May 2004 - April 2005) in 22 sites distributed along the CarretasPereyra lagoon, located in the Biosphere Reserve La Encrucijada, Chiapas, Mexico. We recorded 11797 individuals (40 species, in 30 genera and 21 families). Dormitator latifrons was the most dominant species in terms of the Importance Value index, IV (23.05\%), followed by Lile gracilis (10.31\%), Poecilia sphenops $(8.60 \%)$ and Poecilia butleri (7.30 \%). D. latifrons also accounted for more than one half of the total biomass (50.14\%). Species richness and Shannon-Wiener's diversity indexes showed similar temporal fluctuations, reaching their highest values during the dry season. The system evidenced temporal variations in salinity, having observed four different regimes: freshwater, oligohaline, mesohaline and polyhaline. Mean richness and diversity indexes achieved their highest values during the mesohaline period. On the other hand, mean abundances (CPUE) were highest during the freshwater period. Canonical correspondence analysis (CCA) indicated that salinity and temperature were the most important environmental parameters affecting associations of fishes in terms of their abundances. Correlation analyses revealed that among the environmental variables measured in this study, transparency showed the most significant negative correlation with fish richness and Shannon-Wiener's diversity index. At a local scale, results suggest that spatial and temporal distribution of fish assemblages are determined by differences in the regimes of salinity and transparency, primarily driven by freshwater input from rivers. Rev. Biol. Trop. 56 (2): 557-574. Epub 2008 June 30.
\end{abstract}

Key words: fish assemblages, coastal lagoon, spatio-temporal variation, species diversity, environmental factors, La Encrucijada Biosphere Reserve, Chiapas.

Estuaries and coastal lagoons are transition zones located between the sea and freshwater sources, in which populations of marine and freshwater fish species coexist. Fishes inhabit these biotopes either permanently, cyclically or occasionally, making use of the changing environmental conditions. Accordingly, many of these species possess unique physiological adaptations, allowing them to tolerate extreme environmental changes occurring in those ecosystems (McHugh 1985, Day and YáñezArancibia 1985, Claridge et al. 1986, Shih-Rong et al. 1999). Estuaries and coastal lagoons are characterized by low fish diversities but high abundances for some species, especially from the juvenile age groups (Whitfield 1999).

There are, in general, several approaches to understand biological richness and biodiversity in estuaries and coastal zones, with differences between approaches related to variation in 
scale. At biogeographical levels, explanations are sought on processes determining coastal diversity (Ray 1991), while at regional levels, explanations are about similarities or differences between habitat systems (and, consequently, the ecological processes shaping them), on the basis of analyses of fish assemblages (Madrid et al. 1998, Whitfield 1999, Raz-Guzmán and Huidobro 2002, Espino-Barr et al. 2002).

At local levels, research has been done to explain how fish assemble depend on environmental variables (Blaber and Blaber 1980, Gelwick et al. 2001, Ostrand and Wilde 2001, Travers and Potter 2002, Vega-Cendejas and Hernández 2004), or according to their relation to mangrove habitats (Blaber and Milton 1990, Vega-Cendejas 1998, Ley et al. 1999, ShihRong et al. 1999) or, in general, as a function of spatial and temporal variations (Araujo et al. 1998, Hagan and Able 2003, Cabral-Solis and Espino-Barr 2004).

A lagoon system suitable to study fish assemblages is Carretas-Pereyra, located in the Biosphere Reserve "La Encrucijada", comprising one of the terrestrial and marine regions for conservation priority, as established by the Mexican Federal Government (Arriaga et al. 1998, 2000). Carretas-Pereyra is also a RAMSAR site (No. 815) attested by the Convention of Wetlands of International Relevance, as well as one of the Mexican areas for bird conservation (AICAS of México) (Benitez et al. 1999), due to its high diversity, and for holding the most conserved coastal wetland in Mexico. The Carretas-Pereyra is considered a high valued ecosystem, providing important biological resources for smallscale fisheries. These fisheries are basically oriented to capture and commercializing white shrimp (Litopenaeus vannamei) and, in a lower scale, some fish species like mullets (Mugil curema, M. cephalus), snooks (Centropomus robalito, $C$. nigrescens) and freshwater mojarras (Cichlasoma trimaculatum, Amphilophus macracanthus). Despite fishes constitute a fundamental component in the structure and function of these ecosystems, the only documented studies in this region of the Mexican South
Pacific deal with general descriptions of fish richness (Chávez 1979, Castro-Aguirre 1982, Tapia-García et al. 1998, Díaz-Ruiz et al. 2004). Little is known about patterns between fish assemblages and environmental variables, or how these variables determine the spatial and temporal structure of fish assemblages in those habitats; therefore, the purpose of this study is to investigate the influence of environmental parameters on the spatial and temporal variation of fish assemblages in the coastal lagoon Carretas-Pereyra.

\section{MATERIALS AND METHODS}

Study area: the Carretas-Pereyra lagoon is located south of the state of Chiapas, Mexico, in the Biosphere Reserve 'La Encrucijada'. The study area is characterized by large extensions of mangrove vegetation: white mangrove (Laguncularia racemosa) and red mangrove (Rizophora mangle) as the dominant species, as well as remarkable refuges of median rain forest, and the unique flooding community of "zapatón” (Pachira acuatica) (Anónimo 1999).

Carretas-Pereyra is a small (3 696 ha) and warm $\left(29-33{ }^{\circ} \mathrm{C}\right)$ tropical lagoon that consists of several shallow lagoon bodies named Pereyra, Carretas, Bobo and Buenavista, and an estuarine channel known as El Palmarcito (Fig. 1). Freshwater inputs are Coapa, Pijijiapan, El Bobo and Margaritas rivers flowing into this complex lagoon system. From a hydrological point of view it behaves as a freshwater lagoon one half of the year and as an estuarine lagoon the rest of the time (Contreras 1993).

Sampling design: fish assemblages were sampled every month between May 2004 and April 2005 at 22 sites distributed along the Carretas-Pereyra lagoon (Fig. 1). Localities were referenced with a GPS (Magellan, Blazer 12), aiming to include the various habitat types as lagoon, estuarine and inter-lagoon channel. It was also taken into account the presence and absence of riparian vegetation (essentially $R$. mangle forest and L. racemosa). 


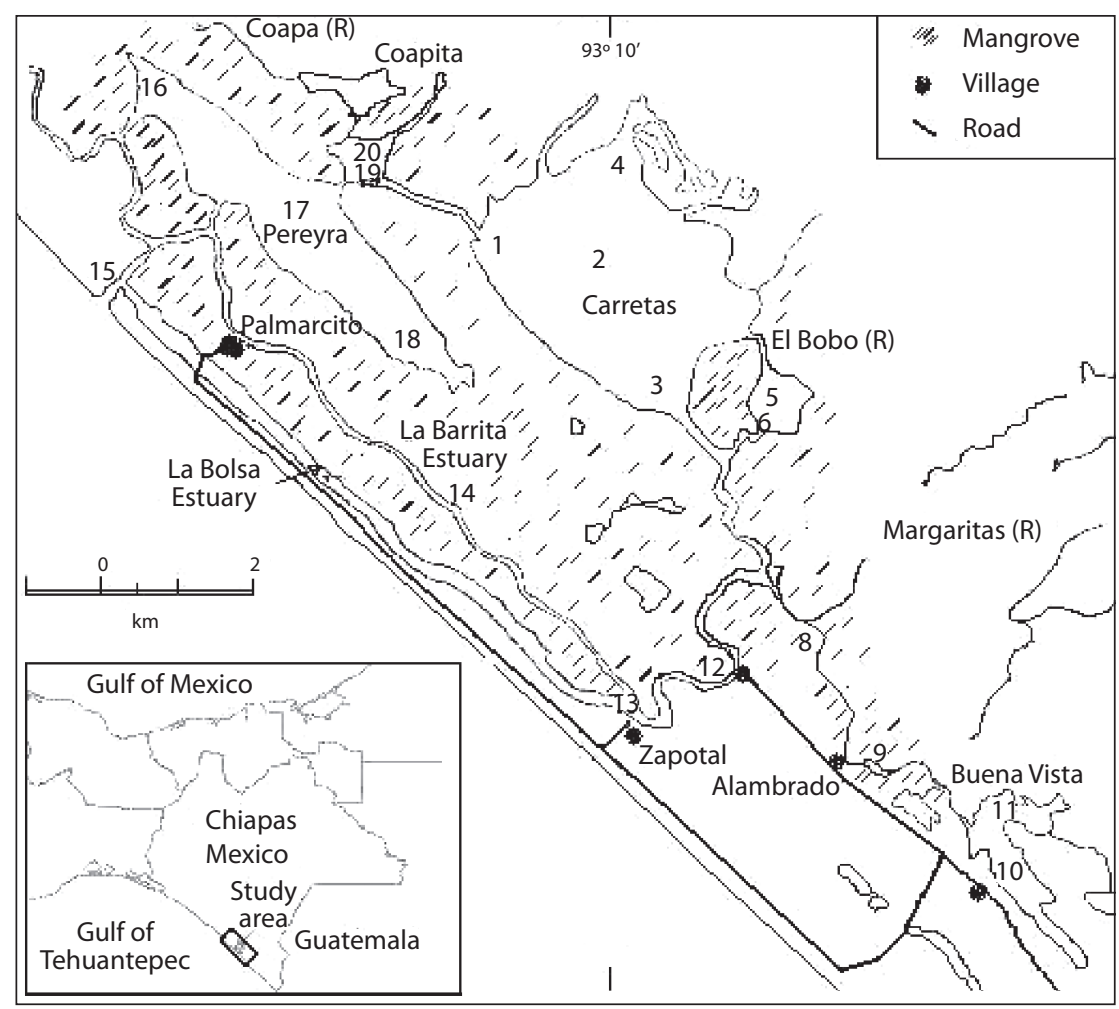

Fig. 1. Study area showing the sampling sites (1-22) in the coastal lagoon system Carretas-Pereyra, Chiapas, Mexico.

Fishes were captured using a drop net (4 $\mathrm{m}$ of diameter and $1.5 \mathrm{~cm}$ stretched mesh). Ten casts per sampling site were executed, after confirming empirically that with this number of casts, the asymptote in the species accumulation curve had been reached. Specimens were preserved in $15 \%$ formaldehyde. Samples were classified in the laboratory and fishes were identified to species level; each fish was counted, measured (SL to nearest $0.1 \mathrm{~cm}$ ) and weighed (W nearest $0.1 \mathrm{~g}$ ). The identified material was deposited in the regional collection of fishes of the Universidad de Ciencias y Artes de Chiapas (MzUNICACH). Before each cast, the following parameters were measured, using a multi-parameter portable meter (Chekmate II system): depth (to the nearest $0.1 \mathrm{~cm}$ ), transparency (Secchi's depth in $\mathrm{cm}$ ), temperature $\left({ }^{\circ} \mathrm{C}\right)$, dissolved oxygen $(\mathrm{DO}, \mathrm{mg} / \mathrm{l})$, total dissolved solids (TDS, mg/l), and $\mathrm{pH}$. Salinity was measured using a conductivity measuring device $(\mathrm{HACH}$, sension5). Fish species taxonomic status was determined considering Nelson (1994) and the recent on-line version of Eschmeyer (1998).

Statistical analysis: numerical abundance for each species was expressed as CPUE (number of individuals captured per ten seine casts). Environmental variables, species composition and structure of fish assemblages were analysed monthly, seasonally, per site, and salinity regime. Descriptors of species diversity considered for these analyses were: richness $(S)$, numerical abundance (CPUE transformed into $\log +1)$ and Shannon-Wiener diversity index ( $H^{\prime}$ base e, used as a measure of heterogeneity of species composition) (Magurran 1988); comparisons between these variables were done by univariate Two-Way ANOVAs. 
Prior to all analyses of variance, assessment of the assumptions of normality (KolmogorovSmirnov test) and homogeneity of variances (Cochran's test) were performed for all the descriptors; variables not fulfilling any of these assumptions, yet being transformed with different functions, were tested by nonparametric analysis of variance (Kruskal-Wallis) (Sokal and Rohlf 1998). Also the "Importance Value" index (IV) was used as a dominance measure, in terms of the relative density (RD), frequency (RF) and biomass (RB) for each species $(I V=R D+R F+R B)$ (Brower and Zar 1977). IV values range between 0 and $3.0(300 \%)$ but they are usually divided by three (referred as the importance percentages) in order to give an overall estimate of the influence of a fish species in the assemblage. Spearman's correlation coefficient was used to examine the simple linear association among environmental variables and CPUE, richness and diversity $\left(H^{\prime}\right)$.

Hydrological relationships (temporal variation) were defined as functions of pluvial precipitation: rain (May-October) and dry (November-April) seasons, respectively (Anonymous 1999). Salinity regimes were established using Venice's classification system with some slight modifications: Freshwater $(0$ to $<0.5)$, oligohaline $(0.5$ to $<5.0)$, mesohaline (5.0 to $<18.0)$ and polyhaline (18 to 30.0$)$ (Paperno and Brodie 2004). Morisita-Horn Index (Wolda 1981) was used as an appropriate measure of similarity between sites according to the mean salinity and the unweight pair group average method (UPGMA) was considered for clustering similar group stations (Krebs 1989).

Species abundances in terms of CPUE ( $\log$ $(\mathrm{CPU}+1))$, and their relation to environmental variables $(\mathrm{pH}$, salinity, DO, TDS, transparency and depth), were analyzed using Canonical Correspondence Analysis (CCA). This ordination method sought to detect patterns of species associations directly related to environmental variables (ter Braak and Verdonschot 1995). In order to reduce the effect of rare species, only species with CPUE $>1 \%$ of the total abundance $(\% \mathrm{~N})$ were considered for CCA.

\section{RESULTS}

Environmental variation: during the study period, water temperature varied from $23.4{ }^{\circ} \mathrm{C}$ (January 2005 at site 3 ) to $36.8{ }^{\circ} \mathrm{C}$ (August 2004 at site 15). The lowest mean temperature recorded in the study was in January $\left(26.87{ }^{\circ} \mathrm{C}, \mathrm{SD}=1.94\right)$, while the highest mean temperature was reached in August (33.34 $\left.{ }^{\circ} \mathrm{C}, \mathrm{SD}=1.67\right)$. Seasonally, temperature in the rainy season (May-October) was significantly higher than in the dry season (November-April) $(\mathrm{F}=22.24, \mathrm{p}<0.0001)$. Spatially, this parameter showed less variation, from an average of $29.45{ }^{\circ} \mathrm{C}(\mathrm{SD}=1.94)$ for site 8 to $31.84{ }^{\circ} \mathrm{C}$ $(\mathrm{SD}=2.12)$ for Site 15 ; in fact, temperature was not significantly different between sites $(\mathrm{F}=0.95, \mathrm{p}=0.520)$ (Fig. 2A).

From a hydrological point of view, the system ranged from freshwater conditions (October 2004, sites 5, 6, 20, 21 and 22) to a high saline condition (April 2005 at site 18, mean salinity $=32.8)$. The lowest mean salinity was recorded in October $(0.39, \mathrm{SD}=0.59)$ and the highest in April (29.27, $\mathrm{SD}=2.13$ ); seasonally, mean salinity was significantly higher in the dry season than in the rainy season $(\mathrm{F}=63.1$, $\mathrm{p}<0.0001)$. Spatially, this parameter did not show a definite gradient; however, there were some areas more influenced by freshwater conditions (stations 8,9,10, 11 and 21, 22) and zones more similar to marine conditions (stations 14,15,16,17 and 18). Salinity averaged from $5.65(\mathrm{SD}=8.09)$ (station 8) to 18.6 $(\mathrm{SD}=11.69)$ (station 15), however these differences were not significant $(\mathrm{F}=1.49, \mathrm{p}=0.082)$ (Fig. 2B).Cluster analysis on mean salinity indicated an spatial homogeneous behaviour for the salinity with a high similarity between sampling sites (>85\%) (Fig. 3 ).

Concentration of dissolved oxygen oscillated between $0.46 \mathrm{mg} / 1$ (May 2004, site 12) and $11.84 \mathrm{mg} / \mathrm{l}$ (November 2004, site 2). The lowest mean DO was registered in October $(2.17 \mathrm{mg} / \mathrm{l}$, $\mathrm{SD}=0.26$ ) while the highest mean was found in November $(4.82 \mathrm{mg} / \mathrm{l}, \mathrm{SD}=0.59)$. Mean DO was significantly higher in the dry season than in the rainy season (Kruskal-Wallis' $\mathrm{H}=25.69$, 

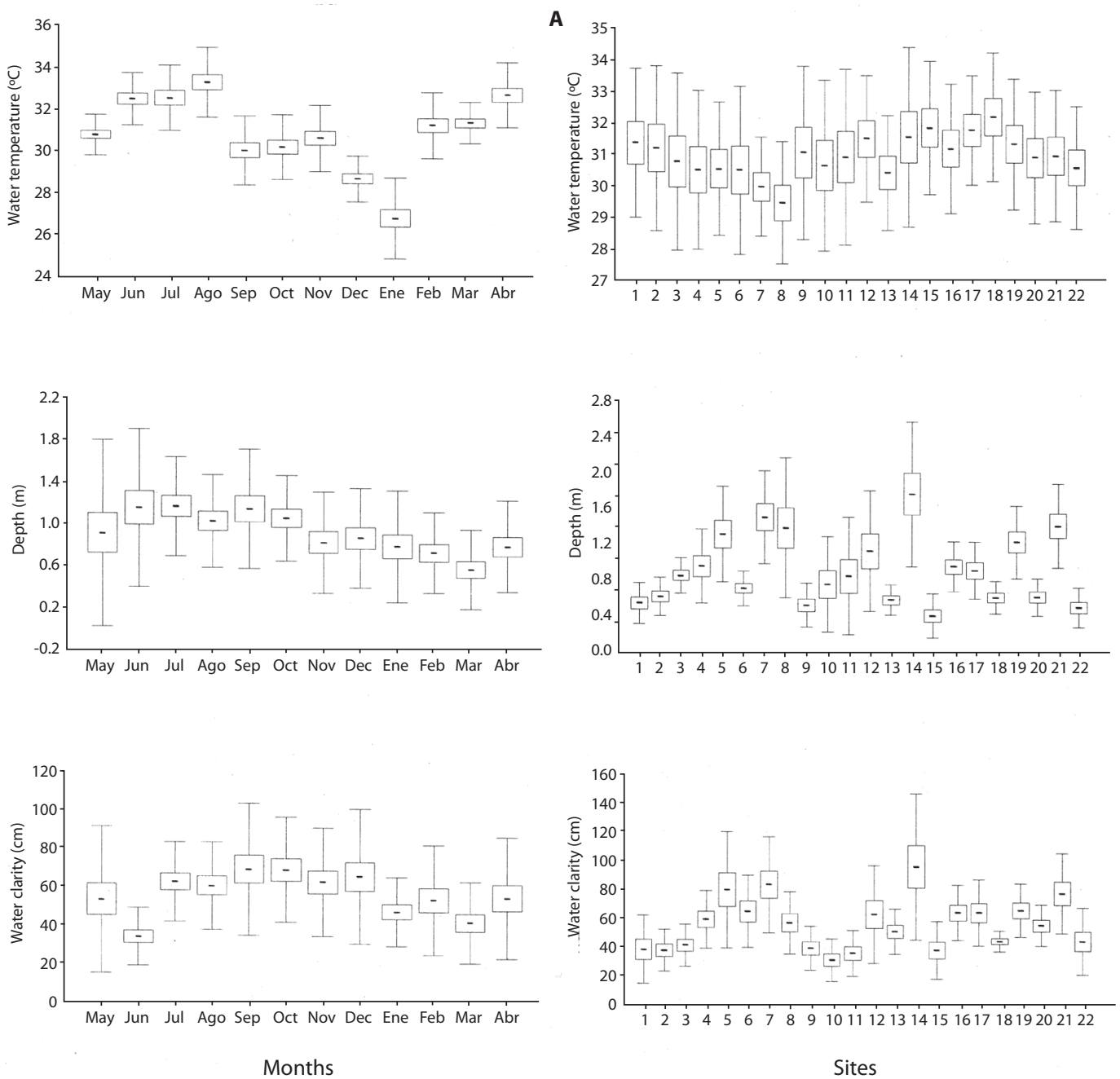

Fig. 2 A. Temporal and spatial variation of Carretas-Pereyra lagoon system (May 04-April 05). Physical parameters: water temperature, depth, water clarity.

$\mathrm{p}<0.0001)$. Spatially, this was the most heterogeneous parameter, leading to significant differences between sites (Kruskal-Wallis' $\mathrm{H}=50.22$, $\mathrm{p}<0.0001$ ), with mean DO varying from $1.14 \mathrm{mg} / \mathrm{l}(\mathrm{SD}=0.68)$ (station 8) to 5.29 $\mathrm{mg} / \mathrm{l}(\mathrm{SD}=2.77)$ (station 1) (Fig. 2B).

TDS fluctuated from $0.1 \mathrm{~g} / 1$ (October 2004, site 1) to $28.10 \mathrm{~g} / \mathrm{l}$ (November 2004, site 22), with the lowest value occurring in October (mean=0.60 g/l, SD=0.59) and the highest in
April (mean=22.41 g/l, SD=1.50). Seasonally, TDS was significantly higher during the dry season (mean=13.11; $\mathrm{SD}=8.55$ ) than in the rain season $($ mean $=5.06, \mathrm{SD}=6.84)(\mathrm{F}=91.27, \mathrm{p}<0.0001)$. Spatially, mean values for this parameter varied from $4.81 \mathrm{~g} / \mathrm{l}(\mathrm{SD}=6.72)$ (site 8) to $15.36 \mathrm{~g} / \mathrm{L}$ $(\mathrm{SD}=10.25)$ (site 14), but these differences were not significant $(\mathrm{F}=1.71, \mathrm{p}>0.05)$ (Fig. $2 \mathrm{~B}$ ).

Water $\mathrm{pH}$ varied from 5.90 (June 2004, site 22) to 10.95 (August 2004, site 21). The lowest 

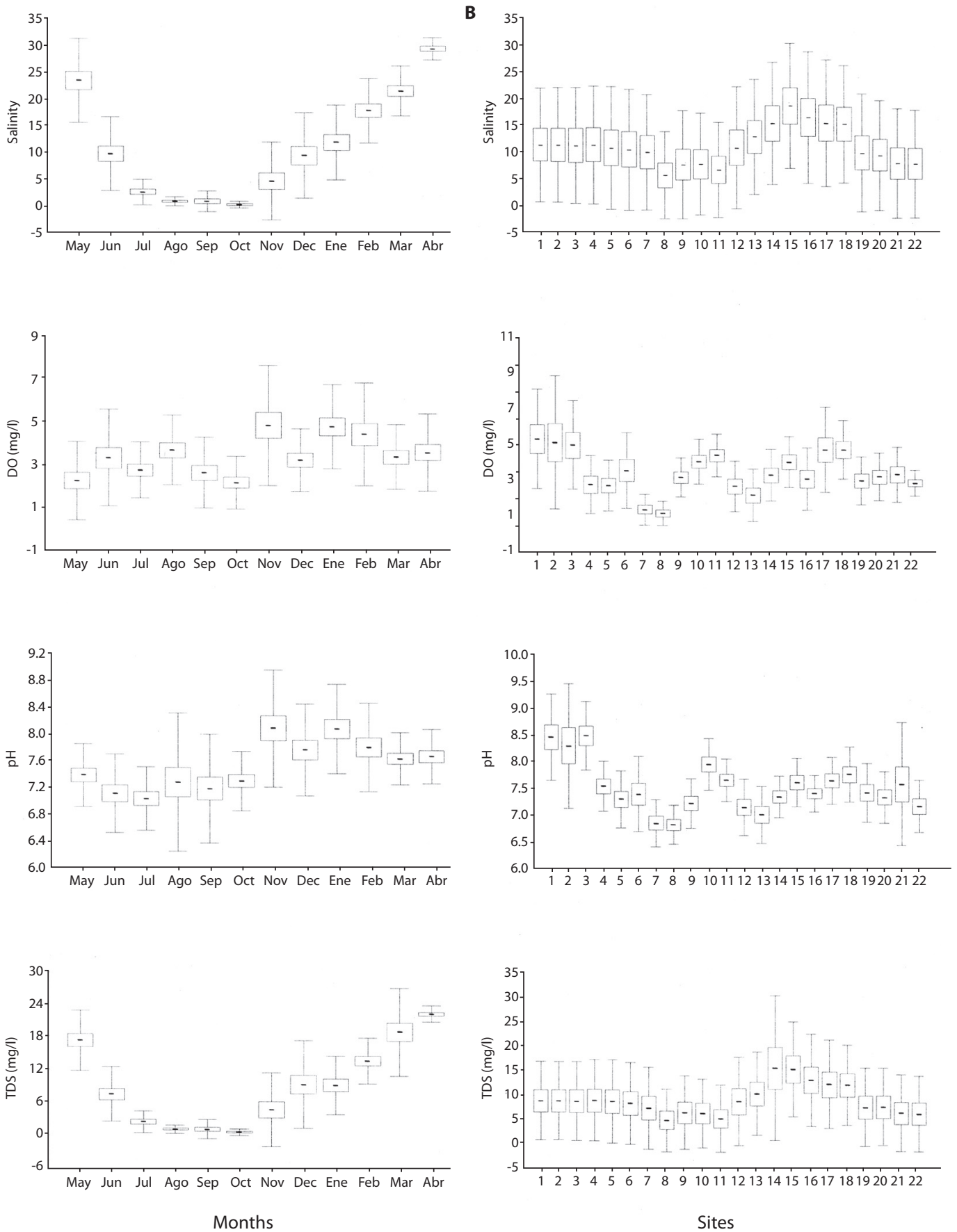

Fig. 2 B. Temporal and spatial variation of Carretas-Pereyra lagoon system (May 04-April 05). Chemical parameters: salinity, dissolved oxygen (DO), $\mathrm{pH}$, total dissolved solids (TDS). Graphs show mean values (dashes), $\pm 1 \mathrm{SD}$ (open boxes) and $\pm 1 \mathrm{SE}$ (vertical lines). 


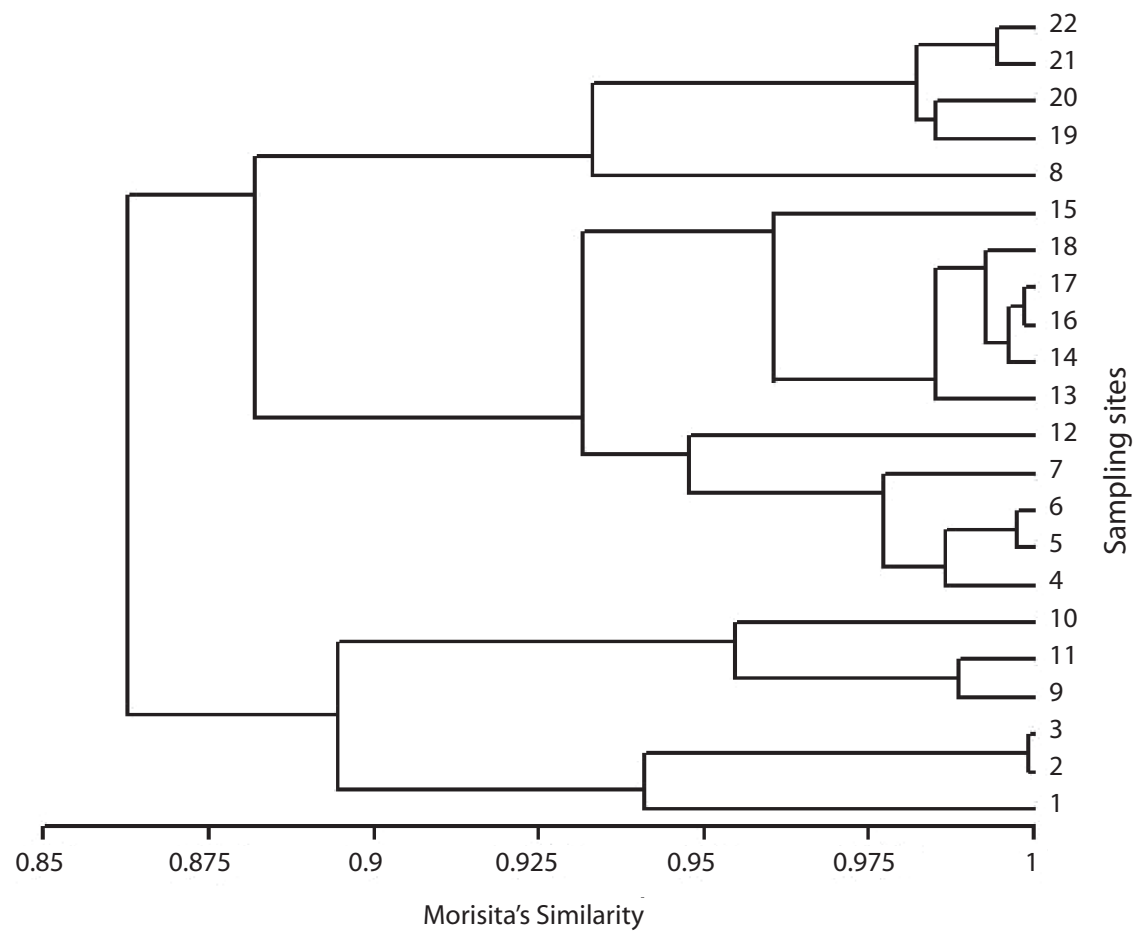

Fig. 3. Cluster analysis by UPGMA considering the annual mean salinity for each sampling site in the Carretas-Pereyra lagoon system. See figure 1 for site numbers.

mean $\mathrm{pH}$ was recorded in July $(7.03, \mathrm{SD}=0.47)$, while the highest occurred in November and January $(8.08, \mathrm{SD}=0.87)$. Seasonally, mean $\mathrm{pH}$ was significantly higher $(\mathrm{F}=101.44, \mathrm{p}<0.0001)$ in the dry season $(7.837, \mathrm{SD}=0.648)$ than in the rainy season $(7.21, \mathrm{SD}=0.668)$. Spatially, the mean $\mathrm{pH}$ varied from $6.83(\mathrm{SD}=0.37)$ (station 8) to 8.94 ( $\mathrm{SD}=0.64)$ (station 3), producing significant differences between sampling sites $(\mathrm{F}=9.89, \mathrm{p}<0.0001)$ (Fig. 2B).

Water transparency varied from $8 \mathrm{~cm}$ (September 2004, site 22) to $170 \mathrm{~cm}$ (September 2004, site 5), with the lowest mean registered in June $(30.43 \mathrm{~cm}, \mathrm{SD}=12.54)$ and the highest in September (69.82 cm, SD=34.41). Seasonally, transparency had a mean of 54.68 $\mathrm{cm}(\mathrm{SD}=28.42)$ in the dry season and $58.75 \mathrm{~cm}$ $(\mathrm{SD}=29.64)$ in the rainy season, without any significant difference $(\mathrm{F}=1.32, \mathrm{p}=0.252)$. This parameter showed higher spatial variation than seasonal variation, as the mean transparency varied from $31.92 \mathrm{~cm}(\mathrm{SD}=14.82)$ (station 10) to $96.75 \mathrm{~cm}(\mathrm{SD}=50.82)$ (station 14$)$, producing significant differences between sampling stations $(\mathrm{F}=6.918, \mathrm{p}<0.0001)$ (Fig. 2A).

Water depth varied from $0.13 \mathrm{~m}$ (March 2005, site 15) to $2.89 \mathrm{~m}$ (September 2004, site $7)$. The smallest mean depth was recorded in March (0.58 m, SD=0.38), and the largest was found in July $(1.18 \mathrm{~m}, \mathrm{SD}=0.47)$. Depth in the rain season (mean $=1.083, \mathrm{SD}=0.609$ ) was significantly larger $(\mathrm{F}=39.95, \mathrm{p}<0.0001)$ than in the dry season (mean $=0.769, \mathrm{SD}=0.453$ ). Spatially, this parameter showed a wide range of variation, from $0.40 \mathrm{~m}(\mathrm{SD}=0.20)$ (site 15) to $1.49 \mathrm{~m}(\mathrm{SD}=0.22)$ (site 14$)$, originating significant differences between sampling sites $(\mathrm{F}=10.65, \mathrm{p}<0.0001)$ (Fig. 2A).

Composition of fish assemblages: a total of 11797 fish specimens were collected, belonging to 40 species, representatives of 30 
genera and 21 families (Table 1). Although fish assemblage was structured by relatively many species, few dominant ones were found. Dormitator latifrons was the most abundant species (14.08\%), followed by Lile gracilis (16.65\%), Poecilia sphenops (14.72\%) and P. butleri (14.55\%); only one species, $D$. latifrons, contributed with an amount as large as $50.14 \%$ of the total biomass (Table 1). All these four species jointly with Amphilophus macracanthus, Atherinella guatemalensis y Centropomus robalito added together an IV of $63.13 \%$ (Fig. 4). Fifty-five percent of the 40 collected species correspond to a eurihaline marine component, followed by a secondary freshwater component (17.5\%), estuarine residents $(15 \%)$, stenohaline marine $(7.5 \%)$, and finally, primary freshwater $(5 \%)$.

\section{Spatial and temporal variation in species} richness and diversity: species richness, ranging from 0 to 16 in the study area, yielded temporal significant differences (Kruskal-Wallis $\mathrm{H}=31.57, \mathrm{p}=0.0007)$; the lowest mean richness was recorded in August (1.82, $\mathrm{SE}=0.36)$ and the highest was found in January $(5.32, \mathrm{SE}=0.80)$ (Fig. 5). Furthermore, richness was significantly larger in the dry season (mean $=3.71$, $\mathrm{SE}=0.25$ ) than in the rainy season (mean $=2.72$,
$\mathrm{SE}=0.19)$ (Kruskal-Wallis $\mathrm{H}=7.05, \mathrm{p}=0.007)$. Significant differences between sites were also found for the mean species richness (KruskalWallis $\mathrm{H}=76.12, \mathrm{p}<0.0001)$; the largest and the lowest means were found in sites 12 (6.58, $\mathrm{SE}=1.17)$ and $6(1.25, \mathrm{SE}=0.41)$, respectively (Fig. 5).

Shannon-Wiener's diversity index showed a pattern similar to that found for species richness (Fig. 5), varying from 0 (for a number of sites in July, August and September) to 1.8 (sites 12 and 18, in September and March, respectively), with significantly different mean values between months (Kruskal-Wallis $\mathrm{H}=31.85, \mathrm{p}=0.0006$ ) and seasons; ShannonWiener's index was higher in the dry season (mean $=0.72, \mathrm{SE}=0.05$ ) than during the rainy season (mean $=0.58, \mathrm{SE}=0.05$ ). There were also spatial differences in the mean ShannonWiener's index of diversity (Kruskal-Wallis $\mathrm{H}=66.83, \mathrm{p}=<0.0001$ ), the largest mean being 1.1 at site 12 , while the lowest estimated as 0.17 for site 6 (Fig. 5). Shannon-Wiener's diversity index was positively correlated to species richness $(\mathrm{r}=0.88, \mathrm{p}<0.0001)$, dissolved oxygen content $(\mathrm{r}=0.16, \mathrm{p}<0.001)$, and $\mathrm{pH}(\mathrm{r}=0.15, \mathrm{p}<0.05)$, but negatively correlated to water transparency $(\mathrm{r}=-0.23$, $\mathrm{p}<0.001)$.

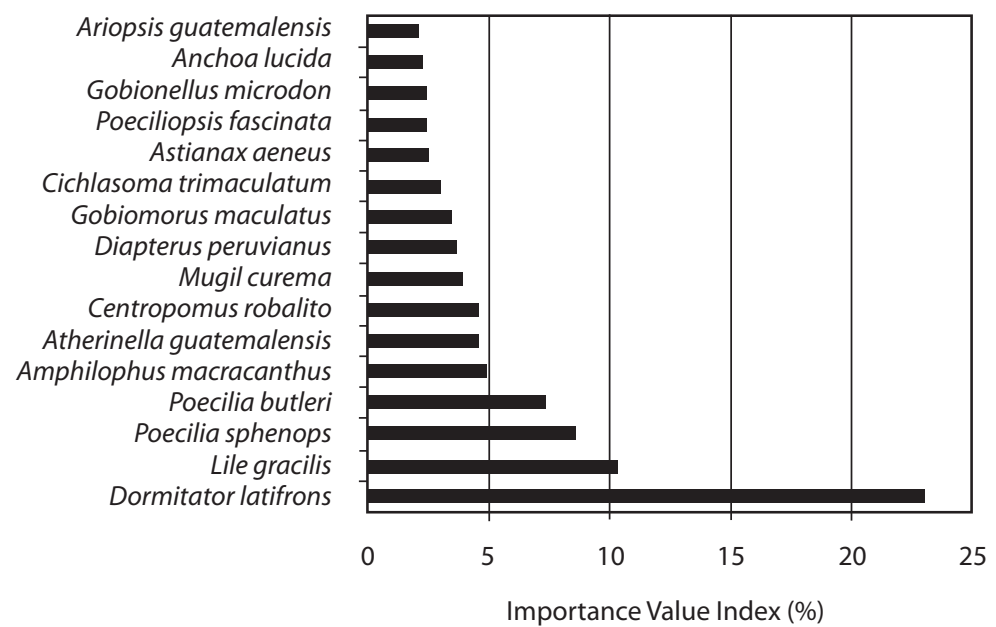

Fig. 4. Dominant fish species collected at Carretas-Pereyra lagoon system, ranked by their Importance Value (IV). 
TABLE 1

Importance Value Index (IV) of the ichthyofauna recorded in the lagunar system Carretas-Pereyra in Chiapas México

\begin{tabular}{|c|c|c|c|c|c|}
\hline Family & Scientific name & $\% \mathrm{~N}$ & $\% \mathrm{~F}$ & $\% \mathrm{~W}$ & IVI \\
\hline Eleotridae & Dormitator latifrons & 14.08 & 4.92 & 50.14 & 23.05 \\
\hline Clupeidae & Lile gracilis & 16.65 & 6.46 & 7.82 & 10.31 \\
\hline Poecilidae & Poecilia sphenops & 14.72 & 2.15 & 8.92 & 8.60 \\
\hline Poecilidae & Poecilia butleri & 14.55 & 3.69 & 3.67 & 7.30 \\
\hline Cichlidae & Amphilophus macracanthus & 4.20 & 4.92 & 5.45 & 4.86 \\
\hline Atherinopsidae & Atherinella guatemalensis & 6.65 & 4.62 & 2.32 & 4.53 \\
\hline Centropomidae & Centropomus robalito & 4.82 & 5.85 & 2.79 & 4.49 \\
\hline Mugilidae & Mugil curema & 2.24 & 4.62 & 4.80 & 3.88 \\
\hline Gerreidae & Diapterus peruvianus & 3.48 & 5.54 & 1.83 & 3.61 \\
\hline Eleotridae & Gobiomorus maculatus & 2.48 & 5.54 & 2.33 & 3.45 \\
\hline Cichlidae & Cichlasoma trimaculatum & 2.39 & 4.92 & 1.46 & 2.93 \\
\hline Characidae & Astyanax aeneus & 2.45 & 3.69 & 1.30 & 2.48 \\
\hline Poeciliidae & Poeciliopsis fasciata & 3.79 & 3.38 & 0.07 & 2.42 \\
\hline Gobiidae & Gobionellus microdon & 0.86 & 5.54 & 0.72 & 2.38 \\
\hline Engraulidae & Anchoa lucida & 1.35 & 4.62 & 0.69 & 2.22 \\
\hline Aridae & Ariopsis guatemalensis & 1.20 & 4.31 & 0.70 & 2.07 \\
\hline Gerreidae & Eucinostomus currani & 0.53 & 3.08 & 0.44 & 1.35 \\
\hline Clupeidae & Lile nigrofasciata & 0.62 & 2.46 & 0.42 & 1.17 \\
\hline Achiridae & Achirus mazatlanus & 0.50 & 2.77 & 0.09 & 1.12 \\
\hline Engraulidae & Anchovia macrolepidota & 0.65 & 2.15 & 0.47 & 1.09 \\
\hline Aridae & Cathorops fuerthi & 0.59 & 2.15 & 0.39 & 1.05 \\
\hline Carangidae & Oligoplites saurus & 0.08 & 1.54 & 0.12 & 0.58 \\
\hline Carangidae & Oligoplites altus & 0.14 & 1.23 & 0.28 & 0.55 \\
\hline Ariidae & Ariopsis seemani & 0.08 & 1.23 & 0.18 & 0.50 \\
\hline Carangidae & Caranx caninus & 0.10 & 0.92 & 0.45 & 0.49 \\
\hline Lutjanidae & Lutjanus argentiventris & 0.05 & 0.92 & 0.22 & 0.40 \\
\hline Centropomidae & Centropomus nigrescens & 0.04 & 0.92 & 0.20 & 0.39 \\
\hline Mugilidae & Mugil cephalus & 0.04 & 0.92 & 0.20 & 0.39 \\
\hline Gerreidae & Gerres cinereus & 0.03 & 0.62 & 0.41 & 0.35 \\
\hline Paralichthydae & Citharichthys gilberti & 0.19 & 0.62 & 0.12 & 0.31 \\
\hline Mugilidae & Mugil hospes & 0.02 & 0.62 & 0.26 & 0.30 \\
\hline Cichlidae & Oreochromis niloticus & 0.01 & 0.31 & 0.41 & 0.24 \\
\hline Centropomidae & Centropomus medius & 0.03 & 0.62 & 0.05 & 0.23 \\
\hline Poeciliidae & Poeciliopsis turrubarensis & 0.29 & 0.31 & 0.09 & 0.23 \\
\hline Elopidae & Elops affinis & 0.02 & 0.31 & 0.17 & 0.16 \\
\hline Engraulidae & Anchoa curta & 0.03 & 0.31 & 0.01 & 0.12 \\
\hline Characidae & Roeboides bouchellei & 0.02 & 0.31 & 0.00 & 0.11 \\
\hline Haemulidae & Pomadasys macracanthus & 0.01 & 0.31 & 0.01 & 0.11 \\
\hline Tetraodontidae & Sphoeroides annulatus & 0.01 & 0.31 & 0.01 & 0.11 \\
\hline Gobiidae & Awaous banana & 0.01 & 0.31 & 0.00 & 0.11 \\
\hline
\end{tabular}

Percentages of the total number of specimens $(11,797)(\% \mathrm{~N})$, of the total weight $(8,6378.29 \mathrm{~g})(\% \mathrm{~W})$ and frequency $(22$ sites) $(\% \mathrm{~F})$ 

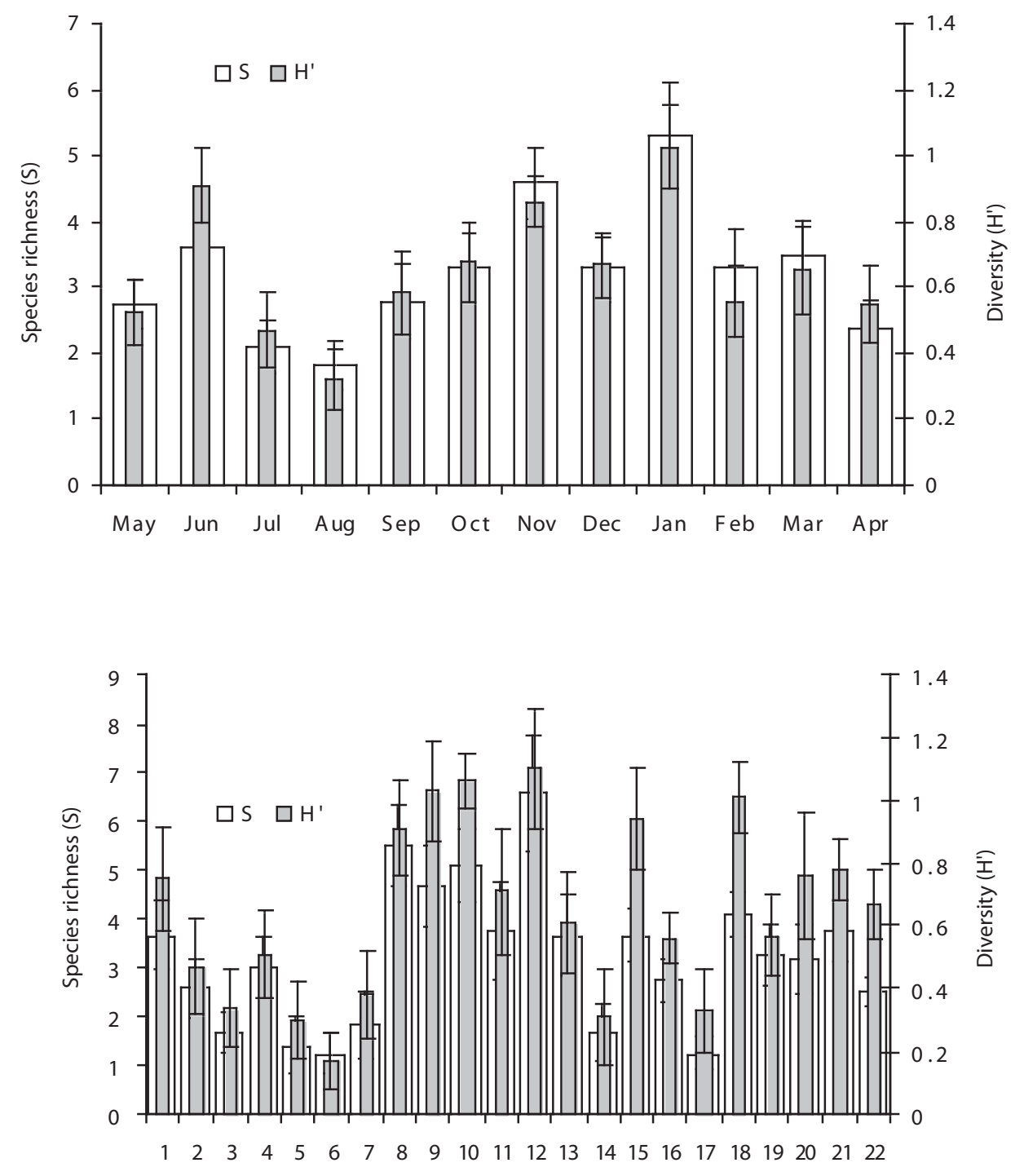

Fig. 5. Temporal and spatial variations in mean fish species richness $(\mathrm{S})$ and mean Shannon-Wiener's diversity index $\left(H^{\prime}\right)$ at Carretas-Pereyra lagoon system (bars $\mathbf{0} 1 \mathrm{SE})$.

Variation of richness, species heterogeneity and abundance by salinity regime: the lowest mean species richness were observed during the oligohaline (July, August, September and November) and polyhaline (March, April and May) periods, increasing during the freshwater regime (October), and reaching its highest value during the mesohaline period (June, December, January and February); these observed differences were statistically significant (Kruskal-Wallis $\mathrm{H}=7.70, \mathrm{p}=0.0490$ ). The mesohaline period allows more chances of interaction of freshwater fish species $(P$. sphenops, $P$. butleri and A. macracanthus) with marine fish species (C. robalito, M. curema and A. guatemalensis), and with typically estuarine species (D. latifrons, A. guatemalensis). A similar pattern was found for the heterogeneity 
of species composition measured by ShannonWiener's index, which attained its highest value in the mesohaline period (Kruskal-Wallis $\mathrm{H}=9.32$, $\mathrm{p}=0.0232$ ) (Fig. 6).

Contrary to patterns found for richness and Shannon-Wiener's index, the mean abundance (CPUE) achieved its highest value during the freshwater period (Kruskal-Wallis $\mathrm{H}=9.72$, $\mathrm{p}=0.0208$ ) (Fig. 7), which was influenced by three dominant freshwater species (P. sphenops,
P. butleri and A. macracanthus) and three estuarine species (D. latifrons, L. gracilis and A. guatemalensis) (Fig. 4).

Spatial and temporal variation in abundance: mean monthly abundance (CPUE) varied from $12.36(\mathrm{SE}=3.53)$ in August to 94.18 $(\mathrm{SE}=55.82)$ during March, having observed significant differences between months (KruskalWallis $\mathrm{H}=30.96, \mathrm{p}=0.0011$ ) (Fig. 8) and seasons

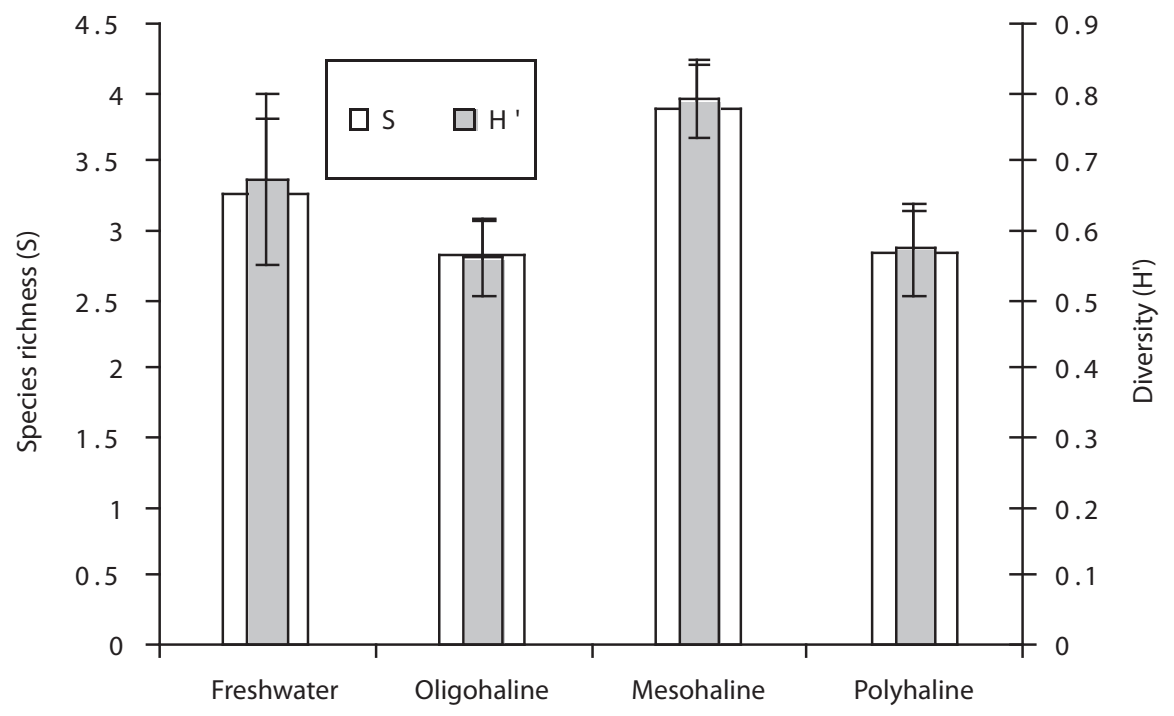

Fig. 6. Mean species richness (S) and mean Shannon-Wiener's diversity index $\left(H^{\prime}\right)$ for each salinity regime found at Carretas-Pereyra lagoon system (bars $\mathbf{0} 1 \mathrm{SE}$ ).

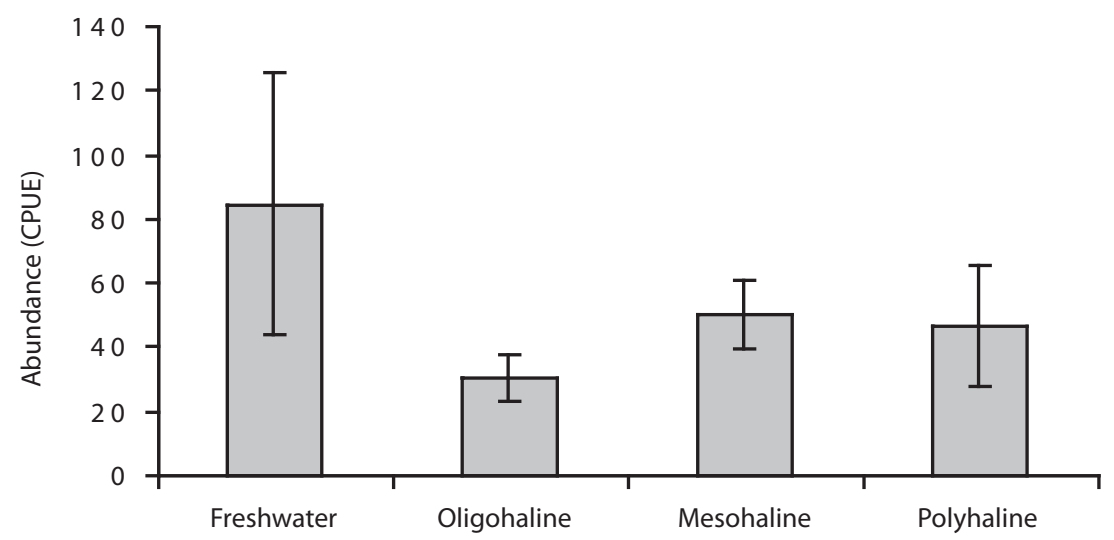

Fig. 7. Mean abundance (CPUE) of fishes for each salinity regime found at Carretas-Pereyra lagoon system (bars $\mathbf{\square} 1 \mathrm{SE}$ ). 


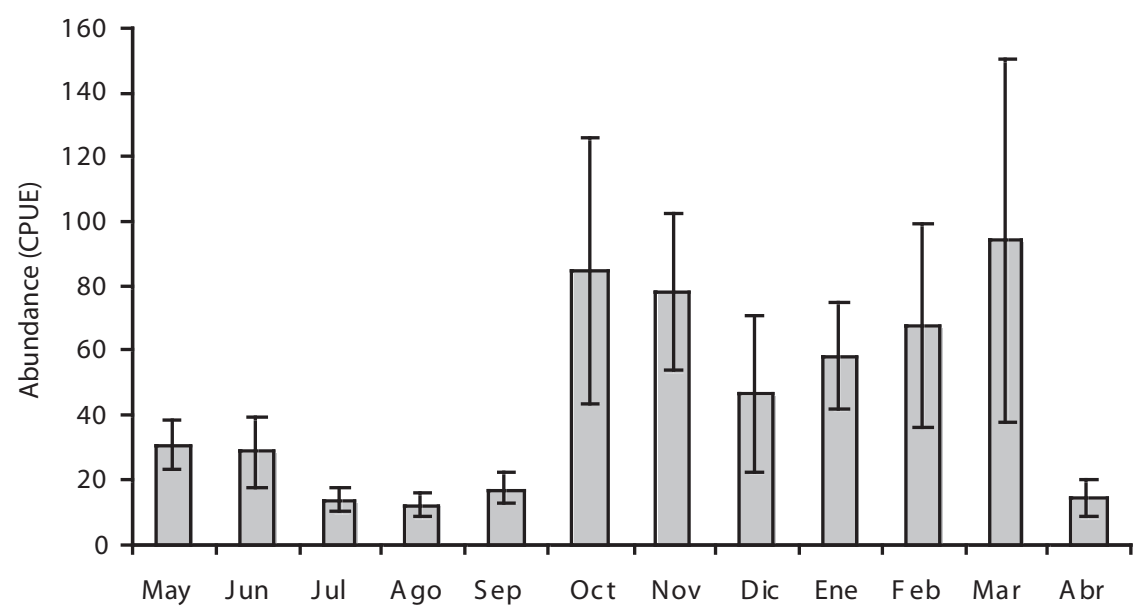

Months

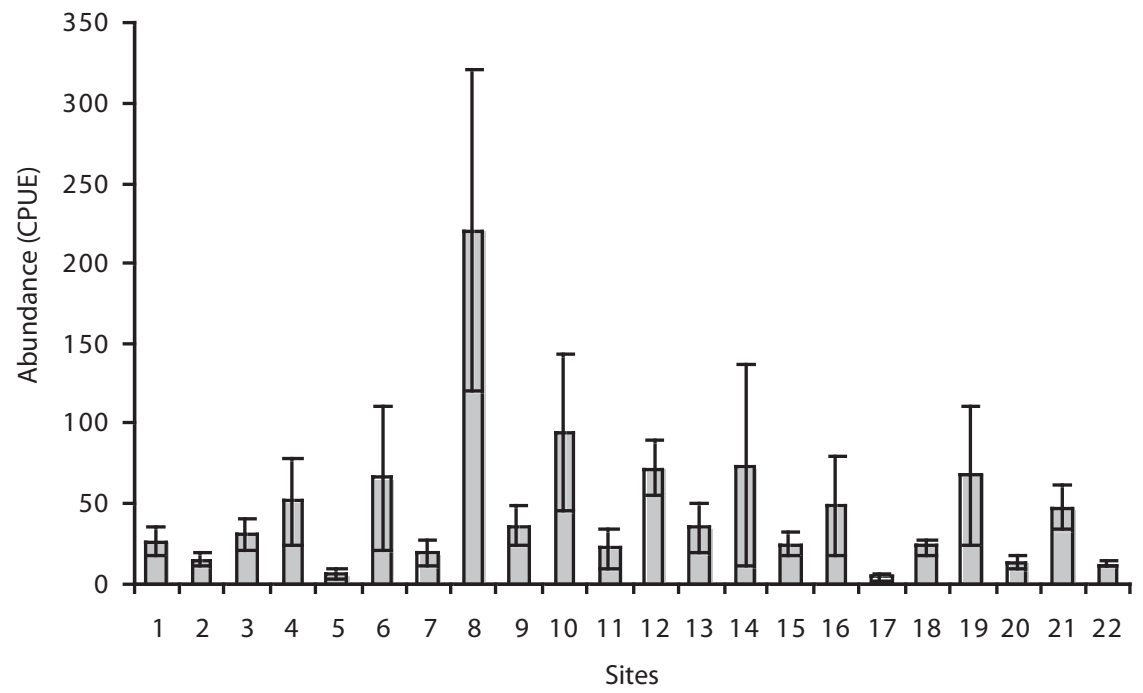

Fig. 8. Temporal and spatial variations in mean abundance (CPUE) of fishes at Carretas-Pereyra lagoon system (bars $\mathbf{\square} 1 \mathrm{SE}$ ).

(Kruskal-Wallis $\mathrm{H}=4.48, \mathrm{p}=0.0341$ ); in the dry season (mean=59.96, $\mathrm{SE}=12.38$ ) abundance was higher than in the rainy season (mean $=31.33$, $\mathrm{SE}=7.43$ ). High abundances observed during October-November were ascribed to abundance peaks of $D$. latifrons and $P$. butleri, while L. gracilis and $P$. sphenops contributed to the peak observed during March. In the JanuaryFebruary period, A. guatemalensis, Astianax aeneus, D. latifrons, L. gracilis, P. butleri and $P$. sphenops accounted for the highest abundance. In December, P. butleri and L. gracilis contributed with more than $50 \%$ of CPUE.

The mean abundance was spatially different (Kruskal-Wallis $\mathrm{H}=59.52, \mathrm{p}<0.0001$ ), the highest attained at site $8(220.25)$ and the lowest at site 17 (3.75) (Fig. 8). The large number of fishes sampled at site 8 was caused 
by the high abundance of two freshwater species, $P$. sphenops y A. aeneus, which jointly accounted for $73 \%$ of the CPUE. Total abundance was positively correlated to species richness ( $\mathrm{r}=0.77, \mathrm{p}<0.0001)$, and had weak positive linear associations to dissolved oxygen $(\mathrm{r}=0.14, \mathrm{p}<0.05)$ and $\mathrm{pH}(\mathrm{r}=0.15, \mathrm{p}<0.05)$; on the other hand, total abundance was weakly and inversely correlated to transparency $(\mathrm{r}=-0.18$, $\mathrm{p}<0.05$ ).

Canonical Correspondence Analysis: associations between environmental variables and the most abundant species are displayed in Fig. 9. The length of the vector for each environmental variable shown in the CCA diagram indicates its importance for explaining a species-environment association and species closer to the vector or to other species points are strongly related (ter Braak and Verdonschot 1995). CCA identified salinity and temperature as the most important physical factor that determine the composition and distribution of fishes in the study area. The first two ordination axis, with eigenvalues $0.16(\mathrm{CC} 1)$ and 0.08 (CC2), accounted for $32.13 \%$ of the total variance of the relationship species-environment. Most of the species in the centre of the CCA diagram are euritopic, and only the marine eurihaline species, Diapterus peruvianus and Centropomus robalito, implied a strong relation to the total dissolved solids, while Anchoa lucida and Lile gracilis were associated to salinity (Fig. 9).

\section{DISCUSSION}

In contrast to temperate zones with clearly defined warm and cold seasons, most of the water bodies in tropical and subtropical regions shows two distinguishable seasons, dry and rainy (Piet 1998). In the majority of tropical water bodies, these seasonal changes are responsible of environmental variations, producing direct impacts on the water levels that affect resource availability such as food, space and spawning areas (Kalk et al. 1979). Hydrodynamics in estuaries and lagoons are strongly affected by entries of marine water and by inflow of freshwater from rivers, influencing biotic and physico-chemical habitat characteristics (Cyrrus and Blaber 1992). The Carretas-Pereyra system is influenced by entry of brackish water from the Gulf of Tehuantepec and by inflow of freshwater from several local rivers (Díaz-Ruiz et al. 2004). Our findings

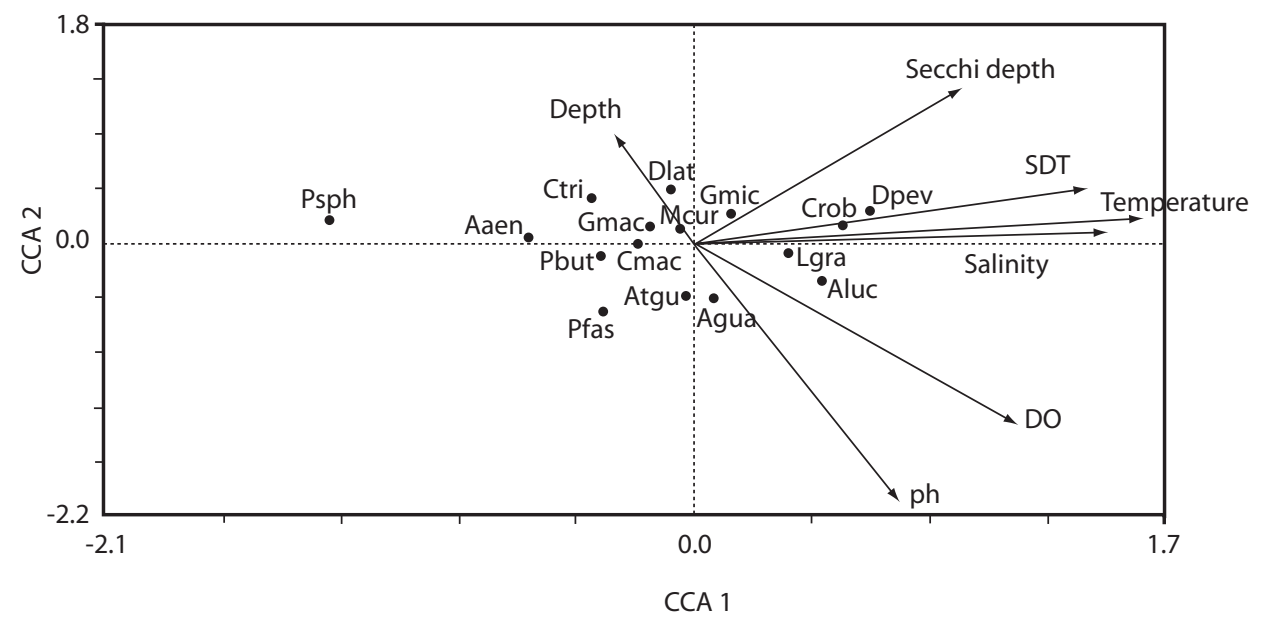

Fig. 9. Plot of species scores with seven environmental variables in the first two Canonical Correspondence Analysis (CCA) axes. Species are abbreviated considering the first letter of the genus followed by the three first letters of the species name. 
point out that freshwater from rivers cause temporal changes in most of the abiotic parameters in the lagoon, particularly on the salinity regimes, transforming it into an eurihaline system. Nevertheless, these changes occur only temporally and not spatially. As far as levels of salinity are concerned, the lagoon system is homogeneous, regardless of the complexity of its structure; this means that no apparent salinity gradient is present in the system. Cluster analysis carried out according to the mean salinity for all sites revealed a higher similarity than $80 \%$ among them (Fig. 3).

Low fish diversity values, but high fish abundances (mainly juveniles) are the main characteristics of estuaries and coastal lagoons (Whitfield 1999). There are several factors that may influence the structure of fish assemblages in such systems. Our analyses revealed that salinity and temperature are the major abiotic parameters driving the structure of fish assemblages in the system Carretas-Pereyra (Fig. 9). This is shown on a temporal basis, where salinity changes are noticeable; thus, in the mesohaline regime occurring at the beginning of the dry season (December-January), intermediate abundance, high richness and high species heterogeneity were found. On the other hand, in the polyhaline and oligohaline regimes, both species heterogeneity and species richness were low. In contrast, during the freshwater regime (October), abundance, richness and Shannon-Wiener's diversity all attained high values: marine species leave the system and it is invaded by freshwater fishes (e.g., Atractosteus tropicus, Roeboides bouchellei, A. aeneus. P. sphenops, Poeciliopsis fasciata) coexisting with estuarine species (D. latifrons, A. guatemalensis, L. gracilis).

At a spatial level, salinity plays a secondary role, and both species heterogeneity and richness seem to be associated predominantly to variations in water transparency. In sites 8 , 9, 10 and 12 , located in the south-eastern portion of the lagoon, we found the highest values of species richness and Shannon-Wiener's species heterogeneity, and intermediate abundance values (Fig. 1 and Fig. 5); these sites are distinguished by their low transparency water. Just the opposite happened at sites 5, 6 and 7: these sites had the lowest values of species heterogeneity and richness, and the highest values of transparency. Poor transparency is one of the attributes of turbidity, which has been cited as one factor that favours the survival of estuarine fishes (Whitfield 1999). Turbidity gradients between the sea and adjacent estuaries provide orientation for the entrance of juvenile fishes that migrate toward the lagoons and estuaries (Blaber 1997). Correlation analyses revealed that among the environmental variables measured in this study, transparency showed the most significant negative correlation with Shannon-Wiener's species diversity. This result agrees with those found in research reports for other lagoon and estuaries (Cyrrus and Blaber 1992, Akin et al. 2005).

This study shows also that diversity of the system Carretas-Pereyra is relatively low, given the high dominance of some particular species (e.g., D. latifrons, L. gracilis), which exhibit a broad tolerance to fluctuations of abiotic conditions. The structure of fish assemblage consisted of approximately the same ecological groups that are common to the estuaries of the Mexican Pacific (Chávez 1979, Yáñez-Arancibia 1978, Castro-Aguirre 1982, Tapia-García et al. 1998, Castro-Aguirre et al. 1999, Díaz-Ruiz et al. 2004, Cabral-Solis and Espino-Barr 2004). However an outstanding fact of this system is the importance of freshwater species, representing the second group in number of species $(22.5 \%)$, due to the contribution of inflowing freshwater of rivers draining to the lagoon; in those rivers, the presence of 21 species has been documented (Corona 2005), many of which penetrate to the lagoon. Marine species were broadly distributed in the area, and their number was greater than of estuarine resident fishes; however, these were much more dominant than marine species, both in abundance and in biomass, a similar pattern found for other lagoons and estuaries (Whitfield 1999, Ley et al. 1999, Akin et al. 2005). The number of species registered in the lagoon Carretas-Pereyra is higher than the 
40 species documented in this study; Villatoro (2006) documented 55 species using other sampling methods, in addition to the use of drop net (gill nets, fishhooks, long seine). In this respect, comparisons in species richness between the estuaries and lagoons are difficult, due to differences in sampling methods (fishing gears, sampling effort and temporality), geographical variations (Kneib 1997) and size of lagoons (Pérez-Hernández and Torrez-Orozco 2000). Species richness of Carretas-Pereyra lagoon is low, compared to the lagoon systems in the Gulf of Mexico and the Caribbean Sea, including the Terminos lagoon (107 species) (AyalaPérez et al. 2003), Tampamachoco lagoon (179) (Pérez-Hernández and Torrez-Orozco 2000), Tamiahua lagoon (112) (Franco-López and Chávez-López 1992), Laguna Madre (84), Río Lagartos lagoon (81) (Vega-Cendejas and Hernández 2004). However, species richness of Carretas-Pereyra lagoon is very similar to the lagoons of the Mexican Pacific, like the Oriental-Ocidental lagoon (72 species) (Chávez 1979), the Mar Muerto lagoon (66) (TapiaGarcía et al. 1998), the Huizache-Caimanero lagoon (60) (Amezcua-Linares 1977), the Teacapan-Agua Brava lagoon (76) (Álvarez et al. 1986), Cuyutlán lagoon (33) (Cabral-Solis and Espino-Barr 2004), Chantuto-Panzacola lagoon (31) (Díaz-Ruiz et al. 2004).

Coastal lagoons, as transition areas, are important components of the coastal areas, and play a preponderant role in the life cycle of many species. The lagoon system CarretasPereyra is one of the three biggest lagoon systems of Chiapas' coastline; although it was not directly measured, our field observations suggest that the system is an important breeding area for several species, e.g., D. latifrons, L. gracilis, P. sphenops, P. butleri, A. macracanthus, A. guatemalensis, among others. Therefore, identification of the environmental factors interacting with the fish assemblage inside the lagoon on spatial and temporal scales is indispensable for decision-making concerned with conservation of the area and management of local fisheries. At a local scale, our results suggest that spatial and temporal distribution of the fish assemblages is determined by differences in the regimes of salinity and transparency, which are deeply affected by the influence of rivers. The drop of diversity observed in the Carretas-Pereyra lagoon is determined by the dominance of only four species (D. latifrons, L. gracilis, $P$. sphenops and $P$. butleri), which represented around $50 \%$ of the IV. Therefore, the results of this study are consistent with the theory that estuaries and lagoons support a low diversity of species and a high abundance of dominant species.

\section{ACKNOWLEDGMENTS}

We thank the personnel of the Reserva de la Biosfera La Encrucijada for logistic support, and to Adán Gómez González, Víctor Villatoro Álvarez and Fabiola González Velázquez for their collaboration during field and lab work. This research is part of the doctoral dissertation by the first author at CINVESTAV-Mérida. This work was partially funded by a research grant from the Fondo Mixto CONACYT-Gobierno del Estado de Chiapas (CHIS-2005-C03-071).

\section{RESUMEN}

Se evaluó la influencia de los factores ambientales sobre la variación espacio-temporal de los ensamblajes de peces, en el sistema lagunar Carretas-Pereyra, Chiapas, México. Entre mayo de 2004 y abril de 2005, se realizaron 12 muestreos mensuales en 22 sitios. Se recolectaron 11 797 organismos, pertenecientes a 40 especies, representando a 30 géneros y 21 familias. Dormitator latifrons fue la especie dominante en Índice de Valor de importancia, IV (23.05\%), seguida por Lile gracilis (10.31\%), Poecilia sphenops $(8.60 \%)$ y Poecilia butleri $(7.30 \%)$. D. latifrons, contribuyó con $50.14 \%$ de la biomasa total. Los valores de riqueza y diversidad de especies $\left(\mathrm{H}^{\prime}\right)$ mostraron variaciones temporales similares, siendo más altos en la época de secas que de lluvias. El sistema lagunar presentó variaciones importantes en los valores de salinidad con los siguientes regimenes: agua dulce, oligohalino, mesohalino y polihalino. La riqueza media de especies y la diversidad alcanzaron sus valores más altos durante el periodo mesohalino. Contrario a los valores de riqueza y diversidad, la abundancia promedio (CPUE) presentó los valores más altos durante el régimen de agua dulce. 
Palabras clave: ensamblaje de peces, lagunas costeras, diversidad de especies, Carretas-Pereyra, factores ambientales, México.

\section{REFERENCES}

Akin, S., E. Buhan, K.O. Winemiller \& H. Yilmaz. 2005. Fish assemblage structure of Koycegiz LagoonEstuary, Turkey: Spatial and temporal distribution patterns in relation to environmental variation. Estuar. Coast. Shelf S. 64: 671-684.

Álvarez, R.B., F. Amezcua-Linares \& A. Yánez-Arancibia. 1986. Ecología y estructura de las comunidades de peces en el sistema lagunar Teacapán-Agua Brava, Nayarit, México. An. Inst. Cienc. Mar Limnol. UNAM 13: 185-242.

Amezcua-Linares, F. 1977. Generalidades ictiológicas del sistema lagunar costero de Huizache-Caimanero, Sinaloa, México. An. Inst. Cienc. Mar Limnol. UNAM 4: 1-26.

Anónimo. 1999. Programa de manejo Reserva de la Biosfera la Encrucijada. Instituto Nacional de Ecología, México.

Araujo, F.G., A.G. Cruz-Filho \& M.C. Azevedo. 1998. Community structure of the demersal fish of Septembay. Rev. Brasil. Biol. 58: 417-430.

Ayala-Pérez, L.A., J.M. Ramos \& H.D. Flores. 2003. La comunidad de peces de la Laguna de Términos: estructura actual comparada. Rev. Biol. Trop. 51: 783-794.

Blaber, S.J.M. 1997. Fish and fisheries on tropical estuaries. Chapman \& Hall, London, England.

Blaber, S.J.M. \& D.A. Milton. 1990. Species composition, community structure and zoogeography. Mar. Biol. 105: 259-267.

Blaber, S.J.M. \& T.G. Blaber. 1980. Factors affecting the distribution of juvenile estuarine and inshore fishes. J. Fish Biol. 17: 143-162.

Brower, J.E. \& J.H. Zar. 1977. Field and laboratory methods for general ecology. W.C. Brown Co., Dubuque, Iowa, USA.

Cabral-Solis, G. \& E. Espino-Barr. 2004. Distribución y abundancia espacio-temporal de los peces en la laguna de Cuyutlán, Colima, México. Oceánides 19:19-27.
Castro-Aguirre, J.L. 1982. Los peces de la laguna Oriental y Occidental, Oaxaca, México y sus relaciones con la temperatura y salinidad. II. Análisis multifactorial. An. Esc. Nac. Cienc. Biol. México 26: 85-100.

Castro-Aguirre, J.L., H. Espinosa \& J. Schmitter-Soto. 1999. Ictiofauna estuarino-lagunar y vicaria de México. LIMUSA, México D.F., México.

Chávez, A.E. 1979. Análisis de la comunidad de una laguna costera en la costa sur occidental de México. An. Inst. Cienc. Mar Limnol. UNAM 6:15-44.

Claridge, P.N., I.C. Potter \& M.W. Hardisty. 1986. Seasonal changes in movements, abundance, size composition and diversity of the fish fauna of the Severn estuary. J. Mar. Biol. Assoc. UK. 66: 229-258.

Contreras, F. 1993. Ecosistemas costeros mexicanos. CONABIO/UAM, México.

Corona, S.A. 2005. Diversidad íctica en ríos de la vertiente del Pacífico de Chiapas. Rev. Dig. Univ. 6:1-12 (also available online: http://www.revista.unam.mx/vol.6/ num8/art81/int81.htm).

Cyrrus, D.P. \& S.J.M. Blaber. 1992. Turbidity and salinity in a tropical Northern estuary and their influence on fish distribution. Estuar. Coast. Shelf S. 35: 545-563.

Day, J.W. \& A.Yáñez-Arancibia. 1985. Coastal lagoons and estuaries as an environment for nekton, p.17-34. In A. Yáñez-Arancibia (ed.). Fish community ecology in estuaries and coastal lagoons: Towards an ecosystem integration. UNAM, Mexico D.F., México.

Díaz-Ruiz, S., E. Cano-Quiroga, A. Aguirre-León \& R. Ortega-Bernal. 2004. Diversidad, abundancia y conjuntos ictiofaunísticos del sistema lagunar-estuarino Chantuto-Panzacola, Chiapas, México. Rev. Biol. Trop. 52: 187-199.

Eschmeyer, W.N. 1998. Catalog of fishes. Special Publication, California Academy of Sciences, San Francisco, California, USA.

Espino-Barr, E., A. Ruiz-Luna \& A. García-Boa. 2002. Changes in tropical fish assemblages associated with small-scale fisheries: a case study in the Pacific off central México. Rev. Fish Biol. Fisher. 12: 393-402.

Franco-López, J. \& R. Chávez-López. 1992. Síntesis sobre el conocimiento de la ictiofauna de la laguna de Tamiahua, Veracruz, México. Hidrobiológica 3-4: 53-63. 
Gelwick, P.F., S. Alkin, D.A. Arrinton \& K.O. Winemiller. 2001. Fish assemblage structure in relation to environmental variation in a Texas Gulf coastal wetland. Estuaries 24: 285-296.

Hagan, S.M. \& K. Able. 2003. Seasonal changes of the pelagic fish assemblages in a temperate estuary. Estuar. Coast. Shelf S. 56: 15-29.

Kalk, M., A.J. McLachlan \& C. Howard-Williams. 1979. Lake Chilwa, studies of change in a tropical ecosystem. Jonk, The Hague, Netherlands. Monogr. Biol. 35: 462 .

Kneib, R.T. 1997. Early life stages of resident nekton in intertidal marshes. Estuaries 20: 214-230.

Krebs, J.K. 1999. Ecological methodology. Addison Wesley Longman, San Francisoc, California, USA.

Ley, J.A., C. Mclvor \& C.L. Montague. 1999. Fishes in mangrove prop-root habitats of northeastern Florida bay: Distinct assemblages across an estuarine gradient. Estuar. Coast. Shelf S. 48: 701-723.

Madrid, V.J., A.A. Ruiz \& I. Rosado. 1998. Peces de la plataforma continental de Michoacán y sus relaciones regionales en el Pacífico mexicano. Rev. Biol. Trop. 46: $267-276$

Magurran, A.E. 1988. Ecological diversity and its measurement. Princeton University, New Jersey, USA.

McHugh, L.J. 1985. The estuarine ecosystem integrated: Foreword, p. 9-16. In A. Yáñez-Arancibia (ed.). Fish community ecology in estuaries and coastal lagoons: Towards an ecosystem integration. UNAM, Mexico D.F., México.

Nelson, J.S. 1994. Fishes of the world. Wiley, New York, USA.

Ostrand, G.K. \& G.R.Wilde. 2001. Temperature, dissolved oxygen and salinity tolerances of five prairie stream fishes and their role in explaining fish assemblage patterns. T. Am. Fish Soc. 130: 742-749.

Paperno, R. \& R. Brodie. 2004. Effects of environmental variables upon the spatial and temporal structure of fish community in a small, freshwater tributary of the Indian River lagoon, Florida. Estuar. Coast. Shelf S. 61: $229-241$

Pérez-Hernández, M.A. \& R. Torres-Orozco. 2000. Evaluación de la riqueza de especies de peces en lagunas costeras mexicanas: Estudio de un caso en el Golfo de México. Rev. Biol. Trop. 48: 425-438.
Piet, J.G. 1998. Impact of environmental perturbation on a tropical fish community. Can. J. Fish Aquat. Sci. 55: 1842-1853.

Ray, C.G. 1991. Coastal-zone biodiversity patterns. BioScience 41: 490-498.

Raz-Guzmán, A. \& L. Hiudobro. 2002. Fish communities in two environmentally different estuarine systems of Mexico. J. Fish Biol. 61: 182-195.

Shih-Rong, K.L. Hsing-Juh \& S. Kwang-Tsao. 1999. Fish assemblages in the mangrove creeks of northern and southern Taiwan. Estuaries 22: 1004-1015.

Sokal, R.R. \& F. Rolf. 1998. Biometry: The principles and practice of statistic in biological research. Freeman, New York, USA

Tapia-García, M., C. Suárez, G. Cercenares, M. Macuitl \& M. García. 1998. Composición y distribución de la ictiofauna en la laguna del Mar Muerto, Pacífico Mexicano. Rev. Biol. Trop. 46: 277-284.

ter Braak, C.J.F. \& P. Verdonschot. 1995. Canonical correspondence analysis and related multivariate methods in aquatic ecology. Aquat. Sci. 57: 255-289.

Travers, M.J. \& I.C. Potter. 2002. Factors influencing the characteristics of fish assemblages in a large subtropical marine embayment. J. Fish Biol. 61: 764-784.

Vega-Cendejas, M.E. \& S.M. Hernández. 2004. Fish community structure and dynamics in a coastal hypersaline lagoon: Rio Lagartos, Yucatán, México. Estuar. Coast. Shelf S. 60: 285-299.

Vega-Cendejas, M. 1998. Trama trófica de la comunidad nectónica asociada al ecosistema de manglar en el litoral norte de Yucatán. Tesis de doctorado, UNAM, México D.F., México.

Villatoro, A.V. 2006. Riqueza ictiofaunística del sistema lagunar Carretas-Pereyra, Chiapas, México y aspectos tróficos de cinco especies de peces. Tesis de Licenciatura, Universidad de Ciencias y Artes de Chiapas. Tuxtla Gutiérrez, Chiapas, México.

Whitfield, K.A. 1999. Ichthyofaunal assemblages in estuaries: A South African case study. Rev. Fish Biol. Fisher 9:151-186.

Wolda, H. 1981. Similarity indices, sample size and diversity. Oecología 50:47-54.

Yáñez-Arancibia, A. 1978. Taxonomía, ecología y estructura de las comunidades de peces en lagunas costeras 
con bocas efímeras del Pacífico de México. Centro de Cien. Mar Limnol. UNAM Publ. Esp. 2:1-306.

\section{INTERNET REFERENCES}

Arriaga, C.L., D.E. Vázquez, C.J. González, R.R. Jiménez, L.E. Muñoz \& S.V. Aguilar. 1998. Regiones marinas prioritarias de México. Comisión Nacional para el Conocimiento y uso de la Biodiversidad, México. (Downloaded: November 25, 2006 http://www.conabio.gob.mx).
Arriaga, C.L, J. Espinoza-Rodríguez, C. Aguilar-Zúñiga, E. Martínez-Romero, L. Gómez-Mendoza \& E. Loa. 2000. Regiones Terrestres Prioritarias de México. Comisión Nacional Para el Conocimiento y Uso de la Biodiversidad (CONABIO). (Downloaded: November 25, 2006 http://www.conabio.gob.mx).

Benítez, H., C. Arizmendi \& L. Márquez. 1999. Base de datos de las áreas de importancia para la conservación de las aves (AICAS). CIPAMEX, CONABIO, FMCN y CCA, México. (Downloaded: December 20, 2006, http://www.conabio.gob.mx). 